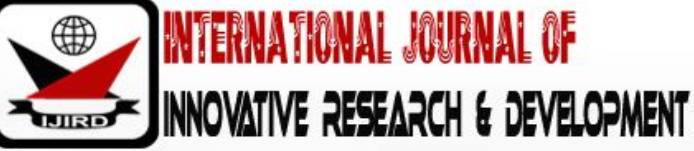

ISSN 2278 - 0211 (Online)

\section{A Comparative Analysis of Existing Conditions of Facilities in the Port-Harcourt Maximum Prison and the United Nations Minimum Standard Rules}

\author{
Bille, Sotonye \\ Research Student, Department of Estate Management, Rivers State University, Port Harcourt, Nigeria \\ Ebiwari Wokekoro \\ Research Supervisor, Department of Estate Management, Rivers State University Port Harcourt, Nigeria
}

\begin{abstract}
:
This research compared the existing conditions of facilities in the Port Harcourt Maximum Prison Facility, Port Harcourt, Rivers State, Nigeria. The objective included assessing the condition of existing facilities in the Port Harcourt Maximum Prison Facility and, comparing the existing facilities using the United Nations Standard Minimum Rules (U.N SMRs).The study adopted the passive observational research survey design. The data for this study was drawn from primary and secondary data. Primary data was collected by administering questionnaires to a sample size of 175, drawn from the Prison staff, while the inmates were carefully observed during the researcher's visits to the prison facility, and also interview with notable key players in the prison facility. Data analysis was based on responses from 158 questionnaires retrieved, representing 90.3\% response rate, and using simple descriptive analytical tools. The study revealed that the existing conditions of the prison is very poor as compared to the United Nations Standard Minimum Rules for Prisoners Treatment, which was supported by the observations of the inmates. A key recommendation of this research is that a multi stakeholders' role is required in the provision and improvement of facilities in prison to meet the International Standard Minimum Rules for the Treatment of Prisoners and the establishment of a Facility Management department in the Port Harcourt Maximum Prison, headed by a Professional Facility Manager, in order to achieve the aim of establishing the Prison facility.
\end{abstract}

Keywords: Prison, facility, facility management, UNMSR

\section{Introduction}

According to the United States Department report on International Prison Conditions in 2012, there are roughly 10.1 million people formally imprisoned worldwide, estimated by the International Centre for Prison Studies' World Prison Brief. The primary international organization seeking to address the innumerable global challenges allied with prisons; is the United Nations Office on Drugs and Crime (UNODC). They are the curators of the prime set of international norms by which prison conditions are evaluated; the U.N Standard Minimum Rules for the Treatment of Prisoners (SMRs)

The SMRs is not a treaty nor a legal binding document. It is an international standard that every government in the United Nations should give favourable consideration to adopt in the administration of their penal institutions. It takes account of social, economic and geographical conditions of the penal institutions, in order to treat inmates as human beings (115th International Training Course to Improve Prison Conditions, 2017).The U.N adopted some basic principles and rules during its first congress at Geneva in 1955, which got approval in 1957 and 1977. These rules seek to set out what is generally accepted as being good principle and practice in the treatment of prisoners and the management of the prison facility.

The Nigerian Prisons are solely run by the Federal Government. This means that it is governed by Federal laws. The prison system has been established long before the amalgamation of 1914. From mere detention centres to Native Authority Prisons and to the current Federal system we have today, the prisons in Nigeria have come a long way. The origin of modern prisons service in Nigeria is 1861, it was the year, western -type of prison was established in Nigeria. The prison regulation was published in 1917 to prescribe admission, custody, treatment and classification procedures as well as staffing, dieting and clothing regimes for the prisons. These processes were limited in general sense; also, there was no particular type of treatment of inmates of the Nigerian Prison (Orakwe, 2015).

However, in 1934, the introduction of relative modernization into the prison service, the Nigerian Prisons Service standing order (Revised Edition), 2011 deals with laws, rules, and regulations governing the Nigerian Prisons Service operations in Nigeria, to this end; the existence of the Nigerian Prisons Service.According to the Nigerian Prisons Service standing orders (Revised edition), 2011 in pursuance with section 16(1)(a) and (b), Cap. P.29 LFN 2004, the standing orders are contained in different parts with job description to staff to administer, control and organize the prisons facility. 
The Prison Facility is designed to be a secure place where rules are followed in order to correct the prisoners. It is meant to be a place where the prisoners are able to develop personally and rebuild their lives so that they are less likely to reoffend once they are back in the society (Richmond, et al, 2012). The job description of the superintendent in charge of every prison facility can be liken to the role of a facility manager, but it is observed that for any facility to function appropriately and achieve its purpose of establishment the facility can only be assessed from the facility manager's perspective. The aim of this study is to compare existing conditions of facilities in the Port Harcourt Maximum Prison with United Nations' Standard Minimum Rules (U.N.SMRs) for treatment of Prisoners.

\subsection{Background Information about the Study Area}

Port Harcourt is the capital and largest city of Rivers state, Nigeria. It lies along the Bonny River and is located in the Niger Delta, originally known as "Igwu-Ocha" by the indigenous Ikwerre, founded in 1913. It was named after Viscount Harcourt, then British Secretary of State for the colonies (Ogionwo, 1979).

It is one of Nigeria's major cities and has been experiencing rapid urbanization, which is tied to social and economic history of the country. Port Harcourt is a major hub of activities and a new frontier of opportunity for a varied range of economic, social and political interests. Figure 1 is a Google Earth map of Port Harcourt showing the study area; the Port Harcourt Prison.

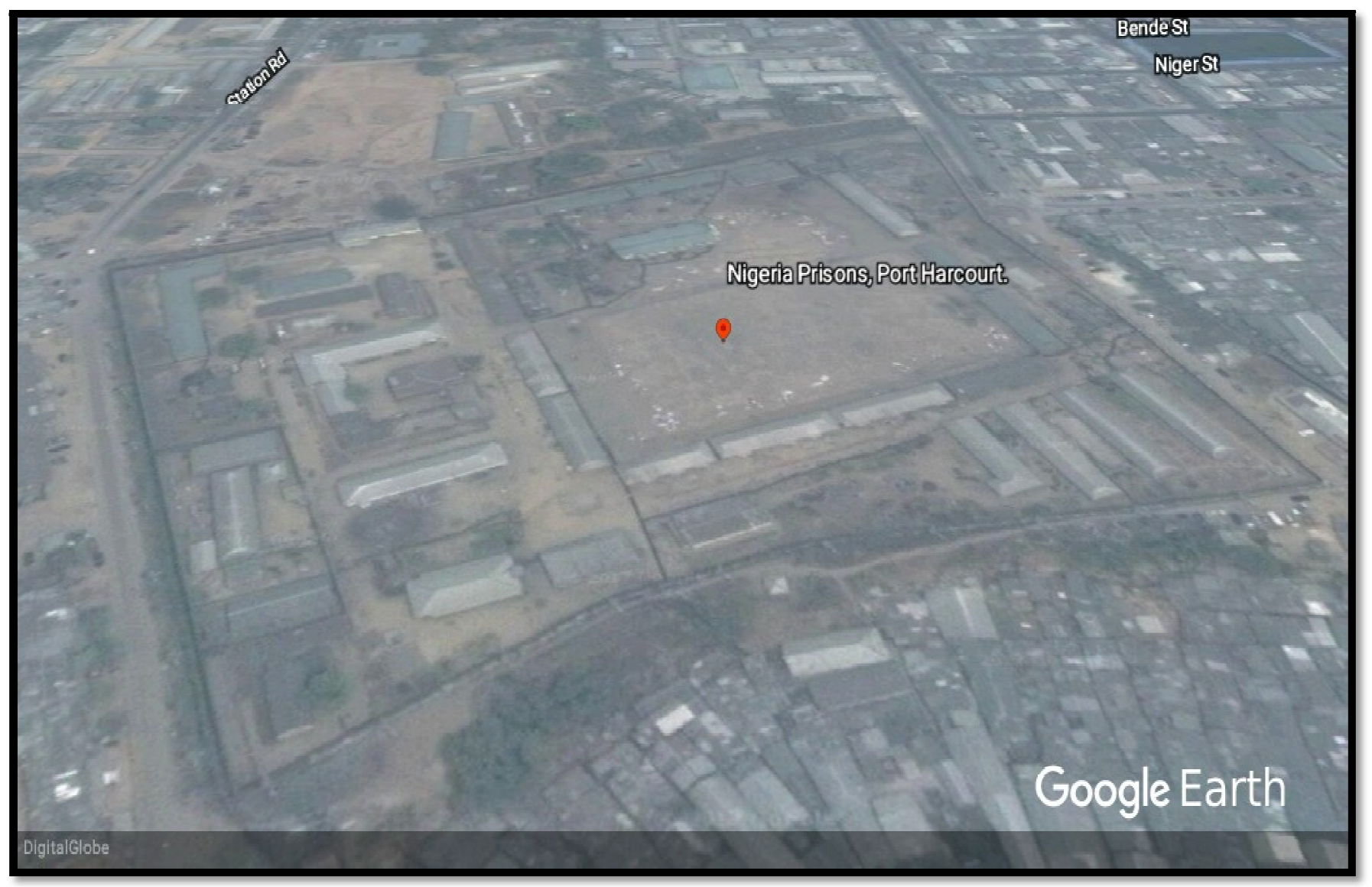

Figure 1: Port Harcourt Maximum Prison Source: Google Earth

The city is a major educational, administrative, and industrial centre, and is regarded as the oil capital of Nigeria, since it hosts most of the nation's multi-national oil and gas exploration and production companies, two refineries; petroleum related service companies, as well as a fast expanding commercial sub-sector (Wokekoro and Owei, 2014).

The Port Harcourt prison facility also referred to as; the Maximum Security Prison is located in Port Harcourt City Council Area of Rivers state, Nigeria. The area has a total land mass of 109 square kilometres. This prison facility consists of offenders of all categories of crime, including awaiting trial, convicts, and condemned criminals of both sexes are kept (Agbakwuru and Godfrey, 2014). It is a prison facility built for both male and female inmates with about $85 \%$ of the facility meant for the male inmates and the about $15 \%$ of the facility for the female inmates, designed to accommodate about 804 inmates (Nwaopara and Stanley, 2015).

\section{Review of Relevant Literature}

\subsection{International Standards and Conditions of Prison Facilities}

In 2010, the UNODC Crime Commission began a much-needed review after its approval in 1957 and 1977. Below is an overview of the condition of a prison facility as recommended by International Standard. 
- Separation of Categories: Prisoners should be kept in different parts of the prison taking account of sex, age, criminal records, psychological fitness, and so on.

- Accommodation: In individual cells or rooms, the required space available per prisoner should not be less than 5.4sq.m, and it is not desirable to have two persons or more in a cell or room.

ii. In the case of shared or dormitory accommodation, prisoners should be suitably selected to associate together, with regular supervision by night, with an average of about 3.4sq.m per prisoner.

iii. Cells should have adequate light, ventilation, heating (if applicable) and weather protection.

iv. Adequate toilet facilities, bathing and shower installations shall be provided to every prisoner. Bath/ Shower at a temperature suitable to the climate as frequently as necessary for general hygiene, according to season and geographical region, but at least once a week in a temperate climate,

v. Prison should include appropriate kitchen facilities and equipment.

vi. Adequate recreation space installations and equipment should be made available.

vii. Sufficient number of furnished offices for prison staff with appropriate lighting and ventilation should be made available.

- Prison Infrastructures: shall meet sanitation, cleanliness, and suitably for detention and imprisonment.

However, other international bodies and countries have also made some contributions about international standards for prison conditions, which are;

- The African Union that created a Special Rapporteur on Prisons and Conditions of Detention in Africa (SRP) in 1996. The SRP's mandate is "to examine the situation of persons deprived of their liberty within the territories of States Parties to the African Charter on Human and Peoples' Rights". From its inception, the SRP has conducted over 25 missions to 23 countries and in its October, 2012 report concluded that; "prison systems in most African countries are in crisis."

- Report on International Prison Conditions- United States Department of State: this report addresses three broad categories of U.S. Government human rights and humanitarian concerns as regards persons held in detention:

$>$ Unsafe prison conditions- overcrowding, poor sanitation, inadequate access to food, potable water, and poor medical facilities

$>$ Mistreatment of Prisoners by Prison staff.

$>$ Inadequate legal protections of prisoners.

\subsection{Research on Similar Studies}

Eze \& Okafor (2007) examined the prison as an instrument of social reformation and rehabilitation using the KiriKiri (Minimum) Prison, Lagos state as a case study. The study showed that most of the inmates were not learning any trade because equipment and tools were in states of disrepair. Also, most of the prisoners belonged to one informal group or the other to protect themselves against other senior prisoners and prison staff considered wicked. Finally, the study found that the conditions in the prisons were very terrible and the prison has no improved facilities.

Ndukwe \& Nwuzor (2014) in a paper examining the Nigerian Prison Service and the challenges of social welfare administration in Abakaliki prison discovered that Abakaliki prison has been unable to meet the Minimum United Nations' Standard in welfare services because of congestion.

In a recent study,Ajah \& Nweke(2017) assessed the level of welfare provisions made available for prison inmates using Abakaliki and Awka Prisons as case studies. This study revealed demographic characteristics of participants, recreational facilities available in the Nigerian Prisons and types of diseases prisoners suffer.

\section{Research Method}

The target population of the study comprises of 302 Prison staff and inmates. Data was obtained from a sample size of 175 prison staff through questionnaire, interview with key informants from the Prison and observing Prison inmates during visit, since interaction with the prison inmates is highly prohibited. Taro Yamane (1965) formula was applied to derive the sample size.

One hundred and seventy five (175) questionnaires were distributed among the Prison staff randomly. However, only 158 questionnaires were properly filled and retrieved. Nevertheless, personal observation by the researcher was carried out by affiliating with a registered Christian Prison Ministry- Rivers Baptist Conference Social Ministry, and the Port Harcourt City Baptist Association, Lydia Auxiliary, all of Port Harcourt, Rivers State, during their visits to the Prison facility for Prison Ministry.

Also, the researcher posed as an Individual Christian Prison Minister on three occasions during the research period, in order to gain access into the prison facility. There were total of eight (8) visits into the prison facility during the period of this study. The research focused on the crucial factors of those that may likely respond within the given time limit, which comprised of the prison staff in departments like; Welfare, Administration, Records, Arms, and Guard Officers. The United Nations Minimum Standard Rules were obtained from the internet.

\section{Results and Discussion}

This section presents results of the analyses carried out in the study, a total number of 175 questionnaires were distributed and only 158 were properly filled and retrieved, representing $90.3 \%$ response rate which was used for the analysis. 


\subsection{Effect of the Physical Condition of the Prison Facility on General Happiness and Satisfaction in Life}

In Table 1, the respondents were asked to rate how the physical condition of the prison facility affect their general happiness and satisfaction. From the data above, 34.2\% (54) responded that the physical condition of the prison facility has an effect to their general happiness and satisfaction in life, while $55.7 \%$ (88) were neutral about the physical condition having to do with their general happiness. Also, 10.1\% (16 Nos.) responded that their happiness and satisfaction of life has no effect with the physical condition of the prison facility.

However, from the responses it indicates that a greater percentage of them have not seen the relationship of their happiness and the physical condition of the prison facility.

From observation, the physical condition of the prison facility has an effect on the inmates because, they keep begging for alms and pleading for help and complaining about the conditions of the prison facility, at the sight of any visitor. Also, the prison staffs are not comfortable with the condition of their physical offices and the available facilities such as electricity supply. The visitors often feel emotional especially on a first visit to the prison facility due to the physical condition.

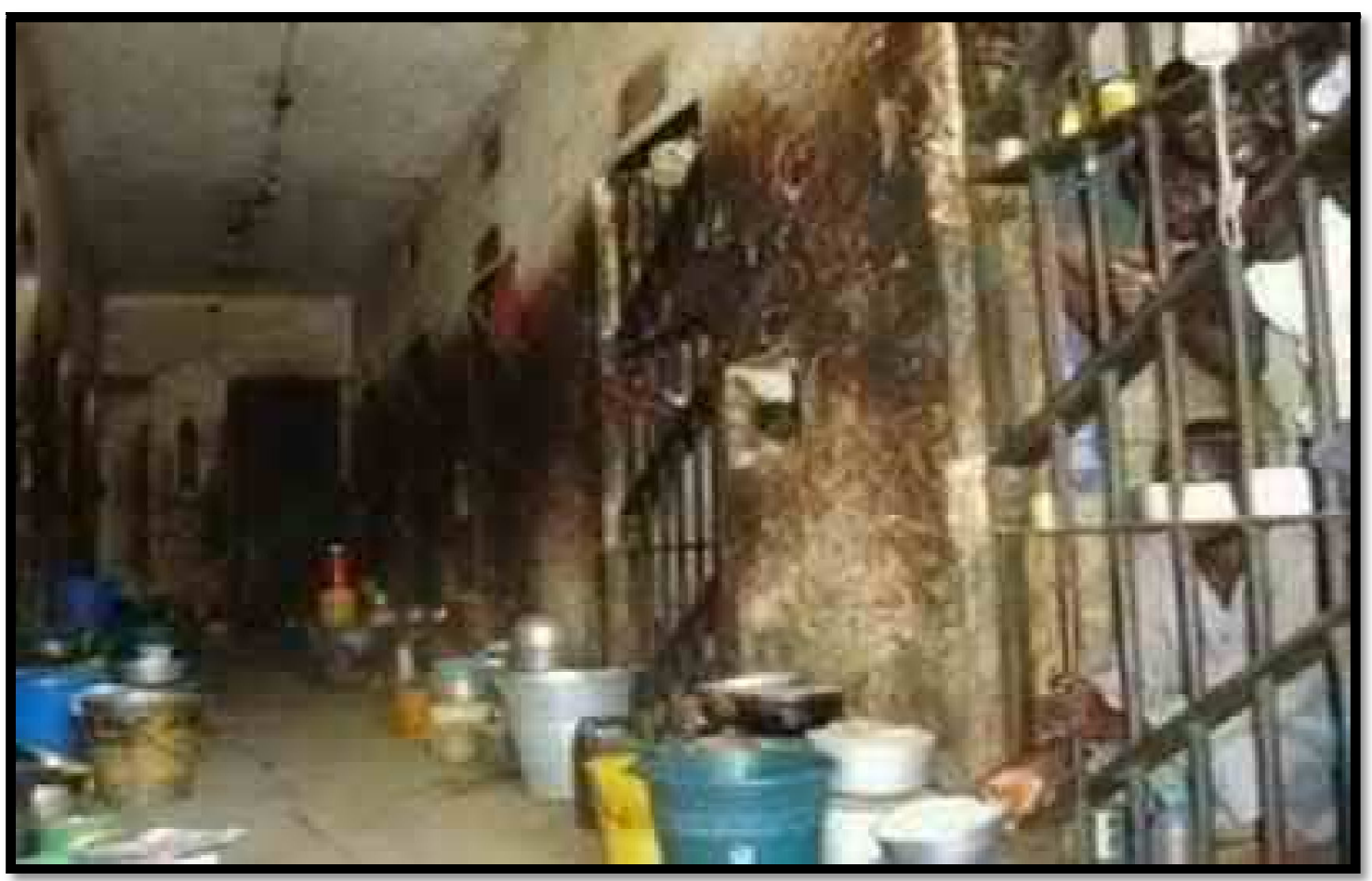

Figure 2: Physical Condition of the Port Harcourt Maximum Prison Male Cell Source: Culled From the Internet

\begin{tabular}{|c|c|c|c|c|c|}
\hline \multicolumn{2}{|c|}{ Responses } & Frequency & Percent & $\begin{array}{c}\text { Cumulative } \\
\text { Percent }\end{array}$ & Cumulative Percent \\
\hline \multirow{4}{*}{} & Very Effective & - & - & - & 5.1 \\
\cline { 2 - 6 } & Effective & 54 & 34.2 & 34.2 & 25.9 \\
\cline { 2 - 6 } & Neutral & 88 & 55.7 & 89.9 & 65.8 \\
\cline { 2 - 6 } & Ineffective & 16 & 10.1 & 100.0 & 85.4 \\
\cline { 2 - 6 } & $\begin{array}{c}\text { Very } \\
\text { Ineffective }\end{array}$ & - & - & - & 100.0 \\
\cline { 2 - 6 } & Total & 158 & 100.0 & 100.0 & \\
\hline
\end{tabular}

Table 1: Effect of the Physical Condition of the Prison Facility on

General Happiness and Satisfaction in Life

Source: Field Survey, 2017

4.2 Comparison of U.N. Msrs Required Conditions of a Prison Facility with Existing Conditions of Port Harcourt Prison Facility

Below is a summary of international required conditions of a prison facility as against conditions found in the study, this international standard is deduced from an overview of the United Nations Minimum Standard Rules, while details from the Port Harcourt prison conditions were deduced from discussions with key informants in the prison facility. 


\begin{tabular}{|c|c|}
\hline $\begin{array}{l}\text { U.N. MSRs Required Conditions of a Prison } \\
\text { Facility }\end{array}$ & $\begin{array}{l}\text { Existing Conditions of the Port Harcourt } \\
\text { Maximum Prison Facility }\end{array}$ \\
\hline $\begin{array}{l}\text { 1. Separation of Categories: Prisoners } \\
\text { should be kept in different parts of the } \\
\text { prison taking account of sex, age, criminal } \\
\text { records, psychological fitness, and so on. }\end{array}$ & $\begin{array}{l}\text { Separation of Categories: In the Port } \\
\text { Harcourt prison facility, prisoners are } \\
\text { only separated according to sex, which is; } \\
\text { male and female. Other basis of } \\
\text { separation are not considered. Prisoners } \\
\text { that are psychologically unfit are together } \\
\text { with other prisoners without any } \\
\text { separation. }\end{array}$ \\
\hline $\begin{array}{l}\text { 2. Accommodation: In individual cells or } \\
\text { rooms, the required space available per } \\
\text { prisoner should not be less than 5.4sq.m, } \\
\text { and is not desirable to have two persons } \\
\text { or more in a cell or room. }\end{array}$ & $\begin{array}{c}\text { Accommodation: The individual cells or rooms } \\
\text { are mainly for government officials who are } \\
\text { brought into the prison as prisoners. The U.N } \\
\text { required space of 5.4sqm is met for the individual } \\
\text { cells or rooms }\end{array}$ \\
\hline $\begin{array}{l}\text { ii. In the case of shared or dormitory } \\
\text { accommodation, prisoners should be } \\
\text { suitably selected to associate together, } \\
\text { with regular supervision by night, with } \\
\text { an average of about 3.4sq.m per prisoner. } \\
\text { iii. Cells should have adequate light, } \\
\text { ventilation, heating (if applicable) and } \\
\text { weather protection. } \\
\text { iv. Adequate toilet facilities, bathing and } \\
\text { shower installations shall be provided to } \\
\text { every prisoner. Bath/ Shower at a } \\
\text { temperature suitable to the climate as } \\
\text { frequently as necessary for general } \\
\text { hygiene, according to season and } \\
\text { geographical region, but at least once a } \\
\text { week in a temperate climate, }\end{array}$ & $\begin{array}{l}\text { ii. The shared or dormitory accommodation is } \\
\text { used for the remaining prisoners, and is about } \\
\text { 0.5sq.m per person, which is below the } \\
\text { international standard of 3.4sq.m per person. } \\
\text { iii. There is very little light and ventilation in the } \\
\text { Port Harcourt prison from data collected from the } \\
\text { questionnaires as well as, observation } \\
\text { iv. Toilet facilities are not adequate, especially the } \\
\text { male prisoners use the bucket system to excrete } \\
\text { and throw into the toilet, and this has led to poor } \\
\text { sanitation in the prison facility. } \\
\text { The toilet facilities in the female section is used } \\
\text { but has issues like bad flushing system and } \\
\text { inadequate water supply. }\end{array}$ \\
\hline $\begin{array}{l}\text { vii. Sufficient number of furnished offices } \\
\text { for prison staff with appropriate lighting } \\
\text { and ventilation should be made available. }\end{array}$ & $\begin{array}{l}\text { v. The Port Harcourt Prison does not have } \\
\text { appropriate kitchen facilities and equipment, for } \\
\text { example; cooking is done with firewood, and } \\
\text { other kitchen equipment are improvised. } \\
\text { vi. There is zero installation for recreation nor } \\
\text { space for such activity. The prisoners are only } \\
\text { allowed to move around the prison yard during } \\
\text { the day, some trading for the prison wards, which } \\
\text { was considered as a form of recreation. } \\
\text { vii. From data collated and observation done by } \\
\text { the researcher, the furniture for prison staff are } \\
\text { grossly insufficient. While carrying out the } \\
\text { research during visits to their offices, some of the } \\
\text { offices could not even provide seat for the } \\
\text { researcher, in the prison yard as well as; their } \\
\text { State Command Office located at Mile 4, Port } \\
\text { Harcourt. There was no electricity supply during } \\
\text { all the visits done to their offices. }\end{array}$ \\
\hline $\begin{array}{l}\text { 3. Prison Infrastructures: shall meet } \\
\text { sanitation, cleanliness, and suitably for } \\
\text { detention and imprisonment. }\end{array}$ & $\begin{array}{l}\text { Prison Infrastructures: The premises is not } \\
\text { properly sanitised. Most of the buildings are due } \\
\text { for maintenance and renovation, it is not clean } \\
\text { nor suitable. This is partly because; prisoners } \\
\text { with psychological problems are meant to use the } \\
\text { same facilities with the other prisoners. }\end{array}$ \\
\hline
\end{tabular}

Table 2: Comparison of U.N. Msrs Required Conditions of a Prison Facility with Existing Conditions of Port Harcourt Prison Facility

The study reveals that the conditions of the Port Harcourt Prison Facility, is far below the United Nations Minimum Standard Rules for Treatment of Prisoners as highlighted in the table 2 above. In the U.N MSR in the institutional personnel section, which states that prison administration shall provide personnel based on their integrity, humanity and professional capacity, for proper administration in the prison facility. A professional Facility manager is needed in order to 
improve the prison facility. Supporting it with the U.N MSR still in the institutional personnel section that states; they also need a conducive environment to perform their required duties in and around the prison facility.

\section{Conclusion and Recommendations}

This study compared the condition of facilities in the Port Harcourt Prison with United Nations Minimum Standard Rules. The study revealed that the condition of facilities are in a deplorable condition considering the physical condition of the Port Harcourt prison facility, for the Prison staff as well as the inmates especially when comparing existing condition of facilities in the prison using the United Nations Minimum Standard Rules. The study concludes that the conditions in Port Harcourt Prison Facility are below United Nations Minimum Standard Rules. The study recommends a multi stakeholders role in the provision and improvement of facilities in prison to meet International Standard Minimum Rules for the Treatment of Prisoners and the establishment of a Facility Management department in the Port Harcourt Maximum Prison, headed by a Professional Facility Manager, in order to achieve the aim of establishing the Prison facility.

\section{References}

i. $\quad$ 115th International Training Course to Improve Prison Conditions, 2017.

ii. Agbakwuru .C. \& Godfrey, E.M. (2016, April). "Incarceration \& the Well-being of Prison Inmates in Nigeria". British Journal of Education, 4, 81-87.

iii. Ajah, B.O \& Nweke, J.O. (2017.). Prison Facilities and the Welfare of Inmates in Nigeria: A Study of Abakaliki and Awka Prisons. World Applied Sciences Journal., Vol. 35, No.3, Pp. 361-369.

iv. Barrett, P \& Baldry, D. (2007). Facilities Management Towards Best Practice . U.K: Blackwell Science.

v. Eze, M\& Okafor, E.E. (2007.). The Prison as an Instrumen of Social Reformation and Rehabilitation: A Study of Nigerian Prisons (Medium) Kiri-Kiri, Lagos. Pakistan Journal of Social Sciences-Medwell Journals., Vol.4(1). Pp:2331.

vi. Microsoft Encarta. (2008).

vii. Ndukwe, C \& Nwuzor, C.I. (2014.). Nigerian Prison Service (NPS) and the Challenges of Social Welfare Administration: A Study of Abakaliki Prison. Journal of Policy \& Development Studies., Vol.9, No.1. ISSN:157-9383.

viii. Nwaopara, U.\& Stanley, P. (2015). Prevalence of Depression in Port Harcourt Prison. J. Psychiatry, 18:340doi.

ix. Ogionwo, W. (1979). The City of Port Harcourt: A Symposium on its Growth and Development. Ibadan, Nigeria.: Heinemann Educational Books.

x. Orakwe, I.W. 2015. Reformation \& Rehabilitation of Prisoners: Achievements \& Challenges. The Reformer, 4(2), 62-66.

xi. $\quad$ Richmond, R.L, T.G. Butler, D. Indig, K.A. Wilhem, V.A Archer, and A.D. Wodak. (2012). "The Challenges of Reducing Tobacco use among Prisoner". Drug and Alchol Review, Vol.31 No.5.

xii. The Nigerian Prison Standing Order, Revised Edition, 2011.

xiii. United Nations Organisation (1977). Standard Minimum Rules for the Treatment of Prisoners. Geneva. Retrieved on 15th May, 2017. from:http:/ / www.ohchr.org/ english/ law/ treatmentprisoners.htm.

xiv. Wokekoro .E. \& Owei, O.B. (2014). "An assessment of Residential Quality of Life in Informal Settlements in PortHarcourt Municipality". IOSR-JHSS, Vol.19, Issues3, e-ISSN, 2279-0837.

xv. Yamane, T. (1967). Statistics,An Introductory Analysis . New York: Harper \& Row. 